\title{
Bone loss, emergencies, vivas and lesions
}

\section{Compiled by Helen Nield}

There are four new titles at the BDA Library for the autumn. To borrow any of these titles please email library@bda.org or call 0207563 4545. Although members are responsible for return postage costs, books are sent out to them free of charge. They may be kept for at least four weeks and can be renewed if not requested by others.

\section{ZERO BONE LOSS CONCEPTS}

Tomas Linkevičius DDS, Dip Pros, PhD

2019; Quintessence Publishing; 304 pp; 1,231

illus; hardback

ISBN: 9780867157994

'Bone loss is still a major issue that dentists encounter, but it is a complication that can be prevented.'

This is a guide for dental implant practitioners to aid in preventing bone loss in their patients. The author believes that by using the different strategies presented in this text, zero bone loss can be achieved for years after treatment. The book is divided into two sections: surgical concepts and prosthetic concepts. The former covers implant design, placement, soft tissues and augmentation whilst the latter looks at types of restorations, abutments and materials. Heavily illustrated but with a balanced amount of text, this book is suitable for an implant specialist rather than a beginner.

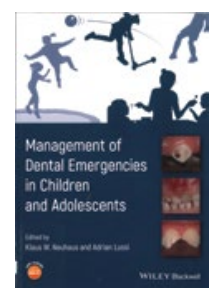

\section{MANAGEMENT OF DENTAL EMERGENCIES IN CHILDREN AND ADOLESCENTS}

Klaus W. Neuhaus and Adrian Lussi (Editors) 2019; John Wiley \& Sons Ltd; 294 pp; paperback ISBN: 9781119372646

'Emergencies in children are different to those for older individuals. As development is still occurring, this has great influence on treatment planning, as well as the ability to provide the best care for the child.'

This newly published textbook edited by a Swiss team of authors is the first to concentrate specifically on acute dental care for young patients and includes explanations on how they differ from adults in terms of treatment and approach. Divided into seven units it covers the general management of emergencies, tooth substance loss, open pulp in permanent and deciduous teeth, missing teeth, managing oral health conditions and treating non-infective dental conditions. Accompanied by a companion website including multiple choice questions, this book is a handy paperback size and contains clear diagrams and images. It can also be read as part of the library's ebook collection - www.bda.org/ebooks.

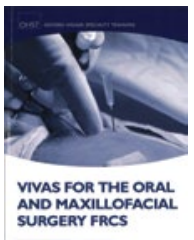

\section{VIVAS FOR THE ORAL AND}

\section{MAXILLOFACIAL SURGERY FRCS}

Johno Breeze, Sat Parmar and Niall M. H. McLeod (Editors)

2019; Oxford University Press; 240 pp; paperback ISBN: 9780198814306

'The FRCS(OMFS) "exit examination”... should be a time to demonstrate to your potential peers what you have learned through all those years of study, and that you have the knowledge to act as a consultant.'

A completely new publication, this is the first time a book of this type has been written for this examination. The authors recommend that anybody studying for this final assessment should find a study partner to act as a 'sounding board and support.' The book itself is split into 15 topic chapters: Head and neck surgical oncology, Orthognathic surgery, Skin cancer, Head and neck trauma, Salivary gland disease, Temporomandibular joint surgery, Bone disease, Oral medicine and pathology,
Craniofacial surgery, Cleft surgery, Dentoalveolar surgery, Reconstructive head and neck surgery, Implants, Aesthetics and Miscellaneous. Each chapter contains a number of vivas consisting of an image and a list of around ten open questions to which answers have been provided.

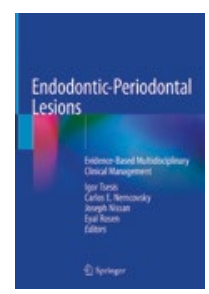

ENDODONTIC-PERIODONTAL LESIONS EVIDENCE-BASED MULTIDISCIPLINARY CLINICAL MANAGEMENT

Igor Tsesis, Carlos E. Nemcovsky, Joseph Nissan and Eyal Rosen (Editors)

2019; Springer Nature; 221 pp; hardback ISBN: 9783030107246

'The association of the degenerative changes in the pulp tissues and periodontal disease presents a clinical and conceptual dilemma ever since it was first described'

Edited by a team based in the periodontology, endodontology and oral rehabilitation departments of Tel Aviv University, this book shows the importance of different dental disciplines working together when tackling these types of lesions, deriving as they do from the aetiologies of their 'associated endodontic and periodontal diseases. The book opens with a discussion of the lesions' origins and subsequent chapters cover their aetiology and classification, endodontic considerations for management, prosthetic considerations for management, periodontal aspects of the lesions, periodontal reconstructive treatment, VRF as an endo-perio lesion, treatment alternatives following tooth extraction, biological complications of dental implants and combined clinical and patient factors in the decision-making process. This book can also be read as part of the library's ebook collection - www.bda.org/ebooks. 